Specijalna edukacija i rehabilitacija

(Beograd), Vol. 11, br. 3. 403-417, 2012.

Milica GLIGOROVIĆ ${ }^{1}$, Nataša BUHA

University of Belgrade

Faculty of Special Education and Rehabilitation
UDK: 376.1-056.313-053.5;

159.922.76.072-056.313;

159.943.072-056.313-053.5

ID: 194205452

Originalni naučni rad

doi:10.5937/specedreh11-2503

\title{
INHIBITORY CONTROL AS A FACTOR OF ADAPTIVE FUNCTIONING OF CHILDREN WITH MILD INTELECTUAL DISABILITY ${ }^{2}$
}

Bearing in mind that the adaptive behaviour is one of the defining parameters of intellectual disability, determining of the influence of inhibitory control on adaptive functioning in children with mild intellectual disability was defined as a basic aim of this research. The sample covered 95 children with mild intellectual disability (MID), of both genders, from 10 to 14 years of age.

By analysis of the data of schools' pedagogical-psychological departments, data on age and intellectual abilities of participants were collected. Inhibitory control was estimated by Go no Go task, consisted of Conflict Response and Response Delay sets. Adaptive skills data were gained on the basis of a standardized interview with special education teachers, by applying of AAMR Scale of adaptive functioning. On the basis of factor analysis, Scale scores were grouped in five factors: Personal independence, Social Independence, Personal and Social Responsibility, Social Adaptability and Personal Adaptability.

Significance of relations among the observed variables was established by Pearson's correlation coefficient, by partial correlation coefficient and multifactorial variance analysis.

1 E-mail: gligorovic@fasper.bg.ac.rs

2 This article is related to the research done in project „Designig a Protocol for Assesing the Educational Potentials of Children with Disabilities as a Criterion for Development of Individual Educational Programs" (No. 179025), financially supported Ministry of Education, Science and Technological Development of the Republic of Serbia. 
Specijalna edukacija i rehabilitacija (Beograd), Vol. 11, br. 3. 403-417, 2012.

Based on the analysis of results a statistically significant relationship between errors in the execution of tasks that belong to the set of conflict motor responses and adaptive functioning $(p \leq 0.000)$ was established. The relationship between errors that belong to the set of the response delay, and adaptive functioning is not statistically significant ( $p=0.324$ ).

Inhibition of the interference response is a significant factor of practical (partial $\eta^{2}=0.227$ ), conceptual (partial $\eta^{2}=0.341$ ) and social (partial $\eta^{2}=0.131$ ) adaptive skills, while the response delay is significantly associated with the conceptual skills $(p=0.029)$ only.

Inhibitory control did not prove itself a significant factor in behaviour problems of externalizing and internalized type.

Key words: mild intellectual disability, inhibitory control, adaptive functioning

\section{INTRODUCTION}

Adaptive behaviour represents a hierarchical multidimensional construct that is constituted by practical, conceptual and social skills, as well as physical and professional competencies (Vig \& Sanders, 2007). The development of adaptive skills is carried out in accordance with the basic course of mental development, from sensorimotor, elementary communication and social skills in early childhood, development of conceptual skills in childhood and adolescence, to a widening range of adaptive competence in adulthood, which is manifested by socially responsible behaviour and adjusting to the environment expectations. It is conditioned by factors that are inherent to an individual (such as cognitive and emotional potential) and to expectations of sociocultural environment in which the individual grows (Burchinal et al., 2008).

As one of the basic mechanisms of executive functions, inhibitory control plays an important role in the behavioural regulation, because it allows limitation or stopping of prepotent competitive behaviour, i.e. responses that are immature, inaccurate or inappropriate (Burle et al., 2004). The possibility of alteration and adaptation of behaviour in different situations of life largely depends on the possibility of inhibition of unwanted or inappropriate types of behaviour. Evaluation 
of verbal and nonverbal information in social interaction (the content of expression, body language, intonation and facial expression of the interlocutors) are the signals by which we modify our behaviour (Carlson, 2005; Kochanska, Murray, \& Harlan, 2000).

Ability to inhibit predominant response, which includes working memory and flexibility of attention, except the inhibitory control, plays an important role in learning, social interaction and respect of rules. The results of a series of studies indicate a significant influence of inhibitory control to academic competence (Blair \& Razza, 2007; Howse et al., 2003; Senn, Espy \& Kaufmann, 2004), social competence (Lengua, 2003; Lengua, Honorado, \& Bush, 2007) and behavioural problems (Kochanski \& Knaack, 2003, Olson et al., 2005). Inhibitory control significantly correlates with the basic domains of adaptive behaviour in childhood and can be a strong predictor of their development (Eisenberg, Hofer, \& Vaughan, 2007).

\section{GOAL OF THE WORK}

Bearing in mind that the adaptive behaviour is one of the defining parameters of intellectual disability (AAIDD, 2010), the main goal of this study is to establish the influence of inhibitory control in adaptive functioning in children with mild intellectual disability (MID).

\section{WORKING METHOD}

\section{Sample}

The sample included 95 children with mild intellectual disability, of both genders, aged from 10 to 14 years. The structure of the sample by age and gender is shown in Table 1 . 
Specijalna edukacija i rehabilitacija (Beograd), Vol. 11, br. 3. 403-417, 2012.

Table 1 - Sample structure by age and gender

\begin{tabular}{lcccccc}
\hline \multirow{2}{*}{ GENDER } & \multicolumn{5}{c}{ Age categories } & \multirow{2}{*}{$\Sigma$} \\
\cline { 2 - 7 } & & $10.0-10.11$ & $11.0-11.11$ & $12.0-12.11$ & $13.0-13.11$ & \\
\hline \multirow{2}{*}{ Female } & Number & 10 & 9 & 11 & 13 & 43 \\
\cline { 2 - 7 } & $\%$ & $10.5 \%$ & $9.5 \%$ & $11.6 \%$ & $13.7 \%$ & $45.3 \%$ \\
\hline \multirow{2}{*}{ Male } & Number & 15 & 12 & 12 & 13 & 52 \\
\cline { 2 - 7 } & $\%$ & $15.8 \%$ & $12.6 \%$ & $12.6 \%$ & $13.7 \%$ & $54.7 \%$ \\
\hline \multirow{2}{*}{$\Sigma$} & Number & 25 & 21 & 23 & 26 & 95 \\
\cline { 2 - 7 } & $\%$ & $26.3 \%$ & $22.1 \%$ & $24.2 \%$ & $27.4 \%$ & $100.0 \%$ \\
\hline
\end{tabular}

The sample included children with unspecified intellectual disability without evident neurological and/or genetic disorders, in order to avoid possible effects of syndrome's specificities on the results.

\section{Instruments and Procedure}

Analyzing the documentation of pedagogical-psychological services in schools, data on age, anamnestic data and intellectual abilities of the participants were collected.

\section{Assessment of Inhibitory Control}

Go no Go Task (Spinella \& Miley, 2004), that consists of two parts is designed to assess inhibitory control. The first part is set named Conflicting Responses Set, in which the participants are expected to respond oppositely to the answer presented by the examiner. The second part is called Responses Delay Set, in which application the participant should delay the reaction during the imitation of given model, upon the agreed signal. Each set consists of 30 items, and the number of incorrect responses and the latency between the order and execution is measured.

\section{Assessment of Adaptive Functioning}

Data on adaptive skills are obtained from standardized interviews with special education teachers, using Scales of adaptive functioning AAMR (AAMR Adaptive Behaviour Scale - School, Second Edition, Lambert et al., 1993). ABS-S: 2 is a behavioural assessment scale for children and adolescents aged $3-21$ years. It is consisted of 16 406 
subscales (domains), with a total of 104 items, divided into two parts - the first is intended for evaluation of adaptive and other one of maladaptive behaviour. The raw scores of each subscale are converted into weighted scores for the population with intellectual disability, standardized by age. Based on factor analysis, the scores of both scales of adaptive behaviour are grouped five factors: Personal Independence (Factor 1), which describes the practical skills, Social Independence (Factor 2), which describes the conceptual skills, Personal and Social Responsibility (Factor 3), which describes social skills, Social Adjustment (factor 4), which primarily describes externalized behaviour problems and Personal Adjustment (Factor 5), which describes the autistic, stereotyped, hyperactive or socially inappropriate behaviour.

\section{Data analysis}

In order to show the basic statistical parameters, the measures of central tendency, measures of variability and range of results were used. The significance of the relationships among observed variables was established by Pearson's correlation coefficient, the coefficient of partial correlation and multifactor analysis of variance (MANOVA).

\section{RESULTS WITH DISCUSSION}

Analysis of results of inhibitory control assessment shows that the mean value of number of errors is significantly higher in the group of tasks that belong to conflict responses, significantly greater than the mean number of errors in a set of tasks in which delayed responses are expected (detailed in Table 2). For our participants much easier tasks are those by which one of the easiest levels of inhibitory control is assessed - the choice between the reaction and non-action.

Resistance to interference response activation, the so-called conflict tasks, are another aspect of inhibitory control. By analyzing the ways of resolving conflict tasks in individuals with typical development, it was established that suppression of tendency to automatically respond to predominant stimulus increases progressively from childhood to late adolescence and adulthood (1929 years of age) (Schroeter at al., 2004; van der Wildenberg \& van 
Specijalna edukacija i rehabilitacija (Beograd), Vol. 11, br. 3. 403-417, 2012.

der Molen, 2004). With that in mind, it is possible that expressed difficulties of predominant response inhibition in children with MID are somewhat overcome in older age groups.

Table 2 - Basic statistic characteristics of results of inhibitory control and adaptive functioning assessment

\begin{tabular}{llcccc}
\hline & & Min & Max & M & SD \\
\hline Go no Go & Conflict Response & 0 & 29 & 7.97 & 5.631 \\
\cline { 2 - 6 } Task & Response Delay & 0 & 16 & 4.04 & 3.857 \\
\hline \multirow{3}{*}{$\begin{array}{l}\text { ABS-S:2 } \\
\text { Factors }\end{array}$} & Factor 1/Personal Independence & 99 & 141 & 135.79 & 8.323 \\
\cline { 2 - 6 } & Factor 2/Social Independence & 88 & 121 & 107.60 & 6.990 \\
\cline { 2 - 6 } & Factor 3/Personal and Social & 93 & 141 & 115.52 & 13.076 \\
\cline { 2 - 6 } & Fesponsibility & 67 & 121 & 95.09 & 13.471 \\
\hline
\end{tabular}

Participants with MID achieve high scores in all assessed areas/ factors of adaptive behaviour. They achieve the best average results in the field of practical skills (Factor 1/ Personal Independence), while the area of conceptual (Factor 2/Social Independence) and social skills (Factor 3/Personal and Social Responsibility), although highly valued, are areas that are according to special educators, slightly less developed in comparison to the practical skills. Relatively high average values in the areas of Social Adjustment (Factor 4) and Personal Adjustment (Factor 5) indicate a relatively low representation of maladaptive behaviour in participants with MID (Buha Djurović and Gligorović, 2009).

Although a statistically significant correlation between IQ and the observed variables were measured only in terms of conceptual skills (Factor 2) ( $r=0.395, p \leq 0.000)$, when analyzing the relationships of inhibitory control, and adaptive functioning, the method of partial correlation was applied with IQ as a control variable (detailed in Table 3). 
Gligorović, M., Buha, N.: Inhibitory control as a factor of adaptive functioning of children with mild intelectual disability

Table 3 - Correlation of the results of inhibitory control and adaptive functioning assessment

\begin{tabular}{lcccccc}
\hline Control variable - IQ & Factor 1 & Factor 2 & Factor 3 & Factor 4 & Factor 5 \\
\hline Conflict & $\mathrm{r}^{\text {part }}$ & -0.399 & -0.473 & -0.239 & -0.148 & -0.253 \\
\cline { 2 - 7 } Responses & $\mathrm{p}$ & $\mathbf{0 . 0 0 0}$ & $\mathbf{0 . 0 0 0}$ & $\mathbf{0 . 0 2 2}$ & 0.160 & $\mathbf{0 . 0 1 5}$ \\
\hline Response & $\mathrm{r}^{\text {part }}$ & -0.177 & -0.313 & -0.210 & -0.197 & -0.176 \\
\cline { 2 - 7 } Delay & $\mathrm{p}$ & 0.092 & $\mathbf{0 . 0 0 2}$ & $\mathbf{0 . 0 4 5}$ & 0.059 & 0.094 \\
\hline
\end{tabular}

Factor 1 - Personal Independence; Factor 2 - Social Independence; Factor 3 - Personal and Social Responsibility; Factor 4 - Social Adjustment; Factor 5 - Personal Adjustment. Statistically significant values are marked (bold).

According to data from Table 3 , the possibility of giving answers that are inconsistent with the given model (a set of conflicting responses) significantly correlates with the practical skills (Factor 1 ), conceptual skills (Factor 2), social skills (Factor 3), and personal adjustment (Factor 5). Response delay errors correlates closely with the conceptual (Factor 2) and social skills (Factor 3), while the significance of relations with externalized behavioural problems (Factor 4) slightly below the statistical significance. Although the relation between inhibitory control and behavioural problems does not reach the threshold of statistical significance, the level of correlation suggests that the tendency to direct, exigent reaction, without considering the context and demands of the situation, may have a role in the manifestation of behavioural problems in children with MID.

Results of Go no Go task are classified in four categories (the transformation is carried out with three sections) for the application of analysis of variance, based on percentile ranks. First category includes participants with the lowest number of errors (below the 25 percentiles), the second $25-50$ percentiles, the third 50-75 percentiles, and fourth one with the highest number of errors (above the 75 percentiles). Table 4 shows distribution of the results of ABS-S: 2 scales to the categories thus obtained. 
Specijalna edukacija i rehabilitacija (Beograd), Vol. 11, br. 3. 403-417, 2012.

Table 4 - Connection of Inhibitory Control and Adaptive Functioning

\begin{tabular}{|c|c|c|c|c|c|}
\hline \multirow{2}{*}{$\begin{array}{l}\text { ABS-S:2 } \\
\text { Factors }\end{array}$} & \multirow{2}{*}{ Category } & \multicolumn{2}{|c|}{ Conflict Responses } & \multicolumn{2}{|c|}{ Response Delay } \\
\hline & & $\mathrm{M}$ & SD & $\mathrm{M}$ & SD \\
\hline \multirow{4}{*}{ Factor 1} & 1 & 138.91 & 5.511 & 137.54 & 5.456 \\
\hline & 2 & 138.45 & 4.103 & 136.81 & 5.558 \\
\hline & 3 & 137.04 & 4.992 & 136.67 & 6.585 \\
\hline & 4 & 129.04 & 12.334 & 132.96 & 12.661 \\
\hline \multirow{4}{*}{ Factor 2} & 1 & 113.41 & 4.876 & 110.69 & 5.574 \\
\hline & 2 & 108.68 & 6.938 & 108.81 & 6.690 \\
\hline & 3 & 107.00 & 4.596 & 107.88 & 6.655 \\
\hline & 4 & 101.83 & 6.569 & 104.36 & 7.538 \\
\hline \multirow{4}{*}{ Factor 3} & 1 & 119.95 & 12.396 & 119.92 & 13.604 \\
\hline & 2 & 116.41 & 11.224 & 114.58 & 12.436 \\
\hline & 3 & 118.35 & 14.006 & 118.04 & 11.525 \\
\hline & 4 & 107.70 & 11.578 & 112.40 & 14.720 \\
\hline \multirow{4}{*}{ Factor 4} & 1 & 97.45 & 10.215 & 100.23 & 12.807 \\
\hline & 2 & 95.86 & 12.245 & 92.84 & 11.420 \\
\hline & 3 & 97.27 & 14.567 & 99.17 & 11.757 \\
\hline & 4 & 90.57 & 15.096 & 92.16 & 16.093 \\
\hline \multirow{4}{*}{ Factor 5} & 1 & 107.09 & 9.596 & 106.46 & 10.301 \\
\hline & 2 & 104.18 & 9.970 & 101.71 & 9.856 \\
\hline & 3 & 104.65 & 10.770 & 108.33 & 10.973 \\
\hline & 4 & 98.57 & 18.032 & 99.96 & 16.979 \\
\hline
\end{tabular}

Factor 1 - Personal Independence; Factor 2 - Social Independence; Factor 3 - Personal and Social Responsibility; Factor 4 - Social Adjustment; Factor 5 - Personal Adjustment.

Based on the results of variance analysis a significant relation between errors in the execution of tasks that belong to the set of conflicting motor responses, and adaptive functioning was established (Wilks' $\lambda=0.575, F(15)=3.480, p \leq 0.000$, partial $\eta^{2}=0.169$ ). The relations between response delay errors and adaptive functioning was not statistically significant (Wilks' $\lambda=0.824, \mathrm{~F}(15)=1.137, \mathrm{p}=0.324$ ).

Table 5 - Relation between inhibitory control and adaptive functioning factors

\begin{tabular}{lcccccc}
\hline & \multicolumn{3}{c}{ Conflict Responses } & \multicolumn{3}{c}{ Response Delay } \\
\cline { 2 - 7 } ABSS:2/Factors & $\mathrm{F}(3)$ & $\mathrm{p}$ & Partial $\eta^{2}$ & $\mathrm{~F}(3)$ & $\mathrm{p}$ & Partial $\eta^{2}$ \\
\hline Factor 1 & 8.715 & $\mathbf{0 . 0 0 0}$ & 0.227 & 1.405 & 0.247 & 0.045 \\
\hline Factor 2 & 15.335 & $\mathbf{0 . 0 0 0}$ & 0.341 & 3.139 & $\mathbf{0 . 0 2 9}$ & 0.096 \\
\hline Factor 3 & 4.463 & $\mathbf{0 . 0 0 6}$ & 0.131 & 1.323 & 0.272 & 0.043 \\
\hline Factor 4 & 1.375 & 0.256 & 0.044 & 2.154 & 0.099 & 0.068 \\
\hline Factor 5 & 1.871 & 0.140 & 0.059 & 2.322 & 0.080 & 0.073 \\
\hline
\end{tabular}

Factor 1 - Personal Independence; Factor 2 - Social Independence; Factor 3 - Personal and Social Responsibility; Factor 4 - Social Adjustment; Factor 5 - Personal Adjustment. Statistically significant values are marked (bold). 
Analysis of the influence of inhibitory control of the individual variables (factors) of adaptive functioning it was determined that it was successful at the tasks that belong to the set of conflicting responses and has significant impact on the area of personal independence (practical skills), social independence (conceptual skills) and personal and social responsibility (social skills) (detailed in Table 5).

The possibility of interference response inhibition, which manifests itself in conflict tasks, has the most significant influence on conceptual skills, causing about $34 \%$ of the variability of results (partial $\eta^{2}=0.341$ ). This unambiguously tells of the importance of this inhibition aspect of a person's ability to achieve a functional interaction with the environment and uses community resources, estimated by the factor of Social Independence.

Starting from the attitude that the development of children with MID is a subject to the same course like development of typical children's population, in which the motor aspect of inhibitory control matures earlier than verbal, somewhere between 6-7 years of age (Welsh, Friedman, \& Spieker, 2006), it can be assumed that the importance of inhibitory control of practical and conceptual, to a lesser degree of social skills (partial $\eta^{2}=0.131$ ) is connected to the insufficient maturity of the higher forms of cognitive control. Theory of mind, as well as the ability to recognize mental states of other people is an essential component of social competence. Inhibitory control and theory of mind have been linked in several ways - by all accounts, the prefrontal cortex is a common neural basis, during the same development period significant changes occur, and in individuals with autism it is characterized by the absence of both capacities (Carlson \& Moses, 2001). More direct evidence of their relation comes from studies that find a statistically significant relationship between inhibitory control and theory of mind (Carlson \& Moses, 2001; Carlson, Moses, \& Claxton, 2004).

Ability to delay motor response was significantly associated with the conceptual skills (Factor 2), while the relationship with other parameters of adaptive functioning is below the level of statistical significance.

Inhibitory control did not appear as a significant factor of externalized (Factor 4) and internalized (Factor 5) behavioural 
problems, which is unexpected if we consider that many life situations require simultaneous coordination of external inputs, the desire for an impulsive reaction and the internal value system (Eisenberg et al., 2004). Area of Social Adjustment (Factor 4) estimates externalized presence of behavioural problems in the domains of social behaviour, adaptability and reliability. According to the results of our previous study, these difficulties are manifested in $20.9 \%$ of children with MID, with the increased tendency toward aggression in conflict situations, temper tantrum, or blaming others for our own mistakes. Behaviour problems are especially manifested in situations that require adjusting to environment by ignoring the rules, resisting the orders, tendency for lying, disrespect of others and public property and the likewise. (Buha Đurović and Gligorović, 2009). Area of Personal Adjustment (Factor 5) includes aspects of behaviour that can be characterized as stereotyped, hyperactive and self-injuring. Bearing in mind that the connection between inhibitory control and adaptive behaviour is the most obvious in cases of behavioural disorders and psychopathology (Nigg, 2001; Overtoom et al., 2002), the lack of a significant relation with the participants of our sample raises the question of the role and dynamics of maturation of different inhibitory mechanisms in behavioural regulation in children with MID.

\section{CONCLUSION}

Based on the analysis of research results, there was a statistically significant relationship among errors in the execution of tasks that belong to the set of conflicting motor responses and adaptive functioning $(\mathrm{p} \leq 0,000)$. The relation between errors that belong to the response delay and adaptive functioning set was not statistically significant $(\mathrm{p}=0.324)$.

Our findings highlight the importance of inhibition interference response in adaptive functioning in the domains of practical (partial $\left.\eta^{2}=0.227\right)$, conceptual (partial $\left.\eta^{2}=0.341\right)$ and social $\left(\right.$ partial $\left.\eta^{2}=0.131\right)$ skills.

Errors in motor response delay were statistically significantly associated with the conceptual skills $(\mathrm{p}=0.029)$, while the relation with 
other factors of adaptive functioning is below the level of statistical significance.

Inhibitory control did not appear as a significant factor in behaviour problems of externalized and internalized type.

Summarizing the findings, we conclude that inhibitory control is an important factor in the development and modulation of various domains of adaptive behaviour, and therefore, it is necessary for it to become an integral part of the rehabilitation of children with intellectual disabilities.

\section{REFERENCES}

1. AIDD - American Association on Intellectual and Developmental Disabilities (2010). Intellectual disability: Definition, classification, and systems of supports. Washington, DC: American Association on Intellectual and Developmental Disabilities.

2. Blair, C. \& Razza, R.P. (2007). Relating effortful control, executive functioning, and false belief understanding to emerging math and literacy ability in kindergarten. Child Development, 78(2), 647-663.

3. Buha-Đurović N., Gligorović M. (2009). Problemi u ponašanju kod dece sa lakom intelektualnom ometenošću, u D. Radovanović (ur.) Istraživanja u specijalnoj edukaciji i rehabilitaciji (str. 145-160), Beograd: CIDD, FASPER.

4. Burchinal, M.R., Roberts, J.E., Zeisel, S.A. \& Rowley, S.J. (2008). Social risk and protective factors for African American children's academic achievement and adjustment during the transition to middle school. Developmental Psychology, 44(1), 286-292.

5. Burle, B. Vidal, F., Tandonnet, C. \& Hasbroucq, T. (2004). Physiological evidence for response inhibition in choise reaction time tasks. Brain and Cognition, 56(2), 153-164.

6. Carlson, S. (2005). Developmentally sensitive measures of executive function in preschool children. Developmental Neuropsychology, 28(2), 595-616. 
Specijalna edukacija i rehabilitacija (Beograd), Vol. 11, br. 3. 403-417, 2012.

7. Carlson, S.M. \& Moses, L.J. (2001). Individual differences in inhibitory control and children's theory of mind. Child Development, 72(4), 1032-1053.

8. Carlson, S.M., Moses, L.J. \& Claxton, L.J. (2004). Individual differences in executive functioning and theory of mind: An investigation of inhibitory control and planning ability. Journal of Experimental Child Psychology, 87(4), 299-319.

9. Eisenberg, N., Hofer, C. \& Vaughan, J. (2007). Effortful control and its socioemotional consequences. In J. J. Gross (Ed.), Handbook of emotion regulation (pp. 287-306). New York, NY: Guilford.

10. Howse, R.B., Lange, G., Farran, D.C. \& Boyles, C.D. (2003). Motivational and self-regulation as predictors of achievement in economically disadvantaged young children. Journal of Experimental Education, 71(2), 151-174.

11. Kochanska, G. \& Knaack, A. (2003). Effortful control as a personality characteristic of young children: Antecedents, correlates, and consequences. Journal of Personality, 71(6), 1087-1112.

12. Kochanska, G., Murray, K.T. \& Harlan, E.T. (2000). Effortful control in early childhood: Continuity and change, antecedents, and implications for social development. Developmental Psychology, 36(2), 220-232.

13. Lambert, N., Nihira, K. \& Leland, H. (1993). Adaptive Behavior ScaleSchool: Examiner's Manual, second edition. Austin, Texas: Pro-ed.

14. Lengua, L.J. (2003). Associations among emotionality, selfregulation, adjustment problems, and positive adjustment in middle childhood. Applied Developmental Psychology, 24(5), 595-618.

15. Lengua, L.J., Honorado, E. \& Bush, N.R. (2007). Contextual risk and parenting as predictors of effortful control and social competence in preschool children. Journal of Applied Developmental Psychology, 28(1), 40-55.

16. Nigg, J.T. (2001). Is ADHD a disinhibitory disorder? Psychological Bulletin, 127(5), 571-598.

17. Olson, S.L., Sameroff, A. J., Kerr, D.C.R., Lopez, N.L. \& Wellman, H.M. (2005). Developmental foundation of externalizing problems 
in young children: The role of effortful control. Development and Psychopathology, 17(1), 25-45.

18. Overtoom, C.C.E., Kenemans, J.L., Verbaten, M.N., Kemmer, C., van der Molen, M.W., van Engeland, H., Koelega, H.S. (2002). Inhibition in children with attention - deficit/hyperactivity disorder: A psychophysiological study of the stop task. Biological Psychiatry, 51(8), 668-676.

19. Schroeter, M.L., Zysset, S., Wahl, M. \& von Cramon, D.Y. (2004). Prefrontal activation due to Stroop interference increases during development - an event-related fNIRS study. Neuroimage, 23(4), 1317-1325.

20. Senn, T.E., Espy, K.A. \& Kaufmann, P.M. (2004). Using path analyses to understand executive function organization in preschool children. Developmental Neuropsychology, 26(1), 445-464.

21. Spinella, M., Miley, W.M. (2004): Orbitofrontal function and educational attainment. College Student Journal, 38(3), 333-338.

22. van den Wildenberg, W.P.M. \& van der Molen, M.W. (2004). Developmental trends in simple and selective inhibition of compatible and incompatible responses. Journal of Experimental Child Psychology, 87(3), 201-220.

23. Vig, S. \& Sanders, M. (2007). Assessment of mental retardation. In Brassard M.R. \& Boehm, A.E. (Eds.), Preschool Assesment: Principles and Practices (pp. 420-447). New York, NY: The Guilford Press.

24. Welsh, M.C., Friedman, S.L. \& Spieker, S.J. (2006). Executive functions in developing children: current conceptualizations and questions for the future. In K. McCartney \& D. Philips (Eds.), Blackwell Handbook of Early Childhood Development (pp. 167-188). Malden, MA: Blackwell Publishing. 
Specijalna edukacija i rehabilitacija (Beograd), Vol. 11, br. 3. 403-417, 2012.

\title{
INHIBITORNA KONTROLA KAO ČINILAC ADAPTIVNOG FUNKCIONISANJA DECE SA LAKOM INTELEKTUALNOM OMETENOŠĆU
}

\author{
Milica Gligorović, Nataša Buha \\ Univerzitet u Beogradu - Fakultet za specijalnu edukaciju i rehabilitaciju
}

\section{Sažetak}

Imajući u vidu da je adaptivno ponašanje jedan od definišućih parametara intelektualne ometenosti, kao osnovni cilj istraživanja definisano je utvrđivanje uticaja inhibitorne kontrole na adaptivno funkcionisanje dece sa lakom intelektualnom ometenošću. Uzorkom je obuhvaćeno 95-oro dece sa lakom intelektualnom ometenošću (LIO), oba pola, uzrasta od 10 do 14 godina.

Analizom dokumentacije pedagoško-psihološke službe škola prikupljeni su podaci o uzrastu i intelektualnim sposobnostima ispitanika. Inhibitorna kontrola je procenjena Kreni-stani zadatkom, koji čine setovi Konfliktni motorički odgovori i Odlaganje motoričkog odgovora. Podaci o adaptivnim veštinama dobijeni su na osnovu standardizovanog intervjua s defektolozima, primenom AAMR Skale adaptivnog funkcionisanja. Na osnovu faktorske analize skorovi Skale su grupisani u pet faktora: Lična samostalnost, Socijalna samostalnost, Lična i socijalna odgovornost, Socijalna prilagođenost i Lična prilagođenost.

Značajnost odnosa između posmatranih varijabli utvrđena je Pirsonovim koeficijentom korelacije, koeficijentom parcijalne korelacije i višefaktorskom analizom varijanse.

Na osnovu analize rezultata je utvrđen statistički značajan odnos između grešaka pri izvršavanju zadataka koji pripadaju setu konfliktnih motoričkih odgovora i adaptivnog funkcionisanja $(\mathrm{p} \leq 0,000)$. Odnos između grešaka koje pripadaju setu odlaganja odgovora i adaptivnog funkcionisanja nije statistički značajan ( $p=0,324)$.

Inhibicija interferentnog odgovora je značajan činilac praktičnih (parcijalni $\left.\eta^{2}=0,227\right)$, konceptualnih (parcijalni $\eta^{2}=0,341$ ) i socijalnih (parcijalni $\eta^{2}=0,131$ ) adaptivnih veština, dok je odlaganje odgovora 
statistički značajno povezano samo sa konceptualnim veštinama $(\mathrm{p}=0,029)$.

Inhibitorna kontrola se nije pokazala kao značajan činilac problema u ponašanju eksternalizovanog i internalizovanog tipa.

Ključne reči: laka intelektualna ometenost, inhibitorna kontrola, adaptivno funkcionisanje

Primljeno: 25. 6. 2012

Prihvaćeno: 14. 7. 2012. 